\title{
PROGRAM PARENTING UNTUK MENUMBUHKAN KESADARAN PENTINGNYA KETERLIBATAN ORANG TUA DI PAUD
}

\author{
Oleh: \\ Ni Gusti Ayu Made Yeni Lestari \\ Jurusan Pendidikan Guru Pendidikan Anak Usia Dini, Fakultas Dharma Acarya Institut \\ Hindu Dharma Negeri Denpasar \\ email: ayuyenilestari88@gmail.com
}

\begin{abstract}
Abstrak
Setiap anak memiliki potensi yang wajib untuk dikembangkan. Potensi yang dimiliki oleh anak tersebut akan berkembang dengan maksimal apabila mendapatkan perawatan, pengasuhan, dan pendidikan yang sesuai dengan kebutuhannya. Semua itu memerlukan dukungan dan kerjasama dari berbagai lingkungan di mana anak berada. Lingkungan yang dimaksud adalah lingkungan keluarga, sekolah, dan masyarakat. Keluarga memegang peranan yang sangat penting karena keluarga merupakan lingkungan pertama dan utama di mana anak mendapat pendidikan. Orang tua yang memiliki pengetahuan tentang pertumbuhan, perkembangan dan pendidikan anak usia dini akan dapat menjadikan anak sebagai generasi yang gemilang, Namun, banyak pula orang tua yang kurang memiliki pengetahuan tentang bagaimana merawat, mengasuh dan mendidik anak berdasarkan ilmu pendidikan anak yang tepat. Hal tersebut berdampak kurang maksimalnya pengembangan potensi yang dimiliki anak. Selain itu, orang tua harusnya memiliki kesadaran yang tinggi akan pentingnya keterlibatan dan kerjasama orang tua dengan pihak lembaga PAUD. Kesamaan dan kesinambungan program PAUD yang dilaksanakan di sekolah dan di rumah akan memberikan dukungan yang maksimal terhadap anak usia dini dalam melewati tugastugas perkembangannya. Orang tua dapat mengikuti program parenting yang dilaksankan oleh lembaga PAUD untuk memperoleh pengetahuan dan ilmu tentang anak usia dini. Program parenting ini dapat diaplikasikan dalam berbagai kegiatan yang tentu saja melibatkan peran dan dukungan orang tua di dalamnya. Melalui program parenting ini juga orang tua dapat memberikan pendidikan dan stimulasi yang sesuai dengan kebutuhan dan tugas-tugas perkembangan sehingga potensianak usia dini dapat berkembang dengan maksimal.
\end{abstract}

Kata kunci: program parenting, keterlibatan orang tua, PAUD

\begin{abstract}
Every child has the potential that be developed. The potential possessed by the child will develop optimally when getting care, and education that suits for their needs. All of that requires the support
\end{abstract}


and cooperation ofvarious environments in which the child located. The environment in question is the family, school and community environment. Families a very important role because the family is the first and foremost environment in which children get education. Parents who have knowledge of growth, development and early childhood education will be able to make children a brilliant generation. However, many parents lack knowledge, nurture and educate children based on appropriate children's education. This has an impact on the lack of maximum development of the potential ofchildren. In addition, parents should have a high awareness of the importance of parental involvement and collaboration with early childhood institutions. The similarity and continuity of programs carried out at school and at home will provide maximum support for early childhood in passing through the tasks of their development. Parents can take part in a parenting program carried out byinstitutions to gain knowledge and knowledge about earlychildhood. This parenting program can be applied in various activities which of course involves the role and support of parents. Through this parenting program parents can also provide education and stimulation in accordance with the needs and tasks of development so that the potential of early childhood can develop optimally.

Keywords: parenting program, parental involvement, early childhood education

\section{PENDAHULUAN}

Anak usia dini adalah individu yang mengalami pertumbuhan dan perkembangan yang bersifat fundamental. Hal ini berarti perkembangan yang terjadi saat ini akan sangat berpengaruh terhadap perkembangan selanjutnya. Untuk itu, anak usia dini yang merupakan titipan dari Tuhan, selain harus dirawat dan dijaga dengan sebaik-baiknya, juga harus diberikan pendidikan yang tepat agar dapat berkembang maksimal sesuai dengan potensi yangdimilikinya.

Menurut Zakiah Daradjat, 1987 (dikutip Syarbini, 2014: 19), terdapat tiga lingkungan yang bertanggung jawab dalam mendidik anak, yaitu keluarga, sekolah, dan masyarakat. Ketiga lingkungan tersebut tidak dapat dipisahkan antara satu dengan lainnya, Namun, dari ketiga lingkungan tersebut, lingkungan keluarga yang memiliki tanggung jawab pertama dan utama terhadap pendidikan yang diperoleh anak usia dini.

Ketika anak mendapatkan stimulasi yang tepat sejak dini, fisik dan psikis anak akan tumbuh dan berkembang sesuai harapan, demikian juga halnya dengan akal(kognitif) anak. Orang tua sebagai sebuah "istitusi pendidikan" yang pertama, tentu harus memiliki pengetahuan dan memahami dengan baik ilmu merawat dan mendidik anak. Namun kenyataannya, tidak semua orang tua mengetahui dan memhami bagaimana merawat dan mendidik anak usia dini dengan baik dan tepat (sesuai dengan kebutuhan dan perkembangananak).

Pada umumnya, orang tua di Indonesia mendidik anak mereka secara autodidak (Helmawati, 2015: 2). Artinya, orang tua mendidik anak berdasarkan pengalaman yang diperolehnya bukan didasarkan pada ilmu 
pendidikan. Hal tersebut tentu saja akan berdampak pada keberhasilan anak dalam melewati tugas-tugas perkembangannya. Mendidik anak berdasarkan pengalaman autodidak yang tidak sesuai dengan ilmu pendidikan anak usia dini tentu akan membuat anak $\mathrm{t}$ idak maksimal dalam tumbuh kembangnya.

Pendidikan yang pertama diperoleh oleh anak berasal dari orang tuanya. Namun, tanpa pendidikan dan pengetahuan yang cukup, orang tua tidak akan dapat memberikan pendidikan yang tepat sesuai dengan kebutuhan anaknya. Dengan demikian, orang tua juga perlu mendapatkan pendidikan. Pendidikan orang tua yang dimaksud dalam hal ini adalah pendidikan yang diberikan kepada orang tua dalam rangka untuk mengetahui dan mengaplikasikan pendidikan yang tepat dalam mendidik anak usia dini terutama saat anak berada dalam lingkungan keluarga bersama orang tuanya di rumah (Latif, dkk; 2013: 260). Merawat dan mendidik anak sejak dini sesuai dengan ilmunya akan memberikan hasil yang maksimal. Anak yang dapat tumbuh dan berkembang sesuai dengan potensinya tentu akan menjadi generasi emas.

Berdasarkan permasalahan di atas, agar orang tua dapat memperoleh pengetahuan dan ilmu pendidikan baik dalam hal merawat, menjaga, mengasuh dan mendidik anak usia dini, orang tua dapat mengikuti program parenting. Melalui program parenting ini, orang tua akan mendapatkan pengetahuan dan keterampilan bagaimana membantu anak usia dini untuk tumbuh dan berkembang sesuai dengan potensinya melalui stimulasiyang tepat. Program parenting juga dapat menambah kesadaran orang tua akan pentingnya terlibat dalam
programPAUD. Orang tua tidak bisa begitu saja menyerahkan pendidikan anaknya kepada lembaga pendidikan. Kesadaran dan keterlibatan aktif orang tua dalam program PAUD akan menunjang keberhasilan anak untuk tumbuh dan berkembang dengan maksimal.

\section{PEMBAHASAN}

\subsection{Konsep Pendidikan Anak Usia Dini}

Pondasi awal seseorang dalam memperoleh pendidikan dalam upaya mengembangkan potensi yang dimilikinya dimulai dari anak usia dini. Anak usia dini berada pada tahap pertumbuhan dan perkembangan yang paling pesat, baik fisik maupun mental. Jadi tepatlah bila dikatakan bahwa usia dini adalah usia emas (golden age), di mana anak sangat berpotensi mempelajari banyak hal dengan cepat.

Mengingat pentingnya pendidikan dimulai dari anak usia dini, dewasa ini telah digalakkan program-program dalam pendidikan anak usia dini. Menurut Undang-Undang Republik Indonesia Nomor 20 Tahun 2003 tentang Sistem Pendidikan Nasional Pasal 1 ayat 14 menyatakan:

Pendidikan anak usia dini adalah upaya pembinaan yang ditujukan kepada anak sejak lahir sampai dengan usia enam tahun yang dilakukan melalui pemberian rangsangan pendidikan untuk membantu pertumbuhan dan perkembangan jasmani dan rohani agar anak memiliki kesiapan dalam memasuki pendidikan lebih lanjut."

Pendidikan anak usia dini pada hakikatnya merupakan salah satu bentuk penyelenggaraan pendidikan yang menitikberatkan pada 
peletakan dasar ke arah pertumbuhan dan perkembangan fisik (koordinasi motorik halus dan kasar), kecerdasan (daya pikir, daya cipta, kecerdasan emosi, kecerdasan spiritual), sosio emosional (sikap dan perilaku), bahasa dan komunikasi sesuai dengan keunikan dan tahaptahap perkembangan yang dilalui oleh anak usia dini. Haliniberarti dalam rentang umur anak usia dini, segala aspek perkembangannya dapat dimaksimalkan untuk menuju tahap perkembangan berikutnya.

PAUD merupakan landasan pendidikan yang menentukan kepribadian anak di masa mendatang, sehingga dikatakan anak pada usia dini adalah usia emas. Oleh karena itu pada usia dini wajib diberikan pendidikan, bimbingan dan pengalaman yang positif, sebab kesannya akan disimpan di otaknya sampaiharituanya (Santoso, 2011: 166). Semua panca indera anak perlu dikembangkan dan dilatih melalui bermain. Dengan bermain lima lingkup pengembangan dapat diberikan pada anak usia dini, yaitu: nilai agama dan moral, fisik, kognitif, bahasa dan sosial emosional.

Sesuai dengan keunikan dan pertumbuhan anak usia dinimaka penyelenggaraan pendidikan bagi anak usia dini disesuaikan dengan tahaptahap perkembangan yang dilalui oleh anak usia dini. Upaya PAUD bukan hanya dari sisi pendidikan saja, tetapi termasuk upaya pemberian gizi dan kesehatan anak sehingga dalam pelaksanaan PAUD dilakukan secara terpadu dankomprehensif.

Pendidikan anak usia dini pada dasarnya meliputi seluruh upaya dan tindakan yang dilakukan oleh pendidik dan orang tua dalam proses perawatan, pengasuhan, dan pendidikan pada anak dengan menciptakan aura dan lingkungan dimana anak dapat mengeksplorasi pengalaman yang memberikan kesempatan kepadanya untuk mengetahui dan memahami pengelaman belajar yang diperolehnya dari lingkungan, melalui cara mengamati, meniru dan bereksperimen yang berlangsung secara berulang-ulang dan melibatkan seluruh potensi dan kecerdasan anak (Sujiono, 2011: 7). Oleh karena itu anak merupakan pribadi yang unik dan melewati berbagai tahap perkembangan kepribadian, maka lingkungan yang diupayakan oleh pendidik dan orang tua yang dapat memberikan kesempatan pada anak untuk mengeksplorasi berbagai pengalaman dengan berbagai suasana, hendaklah memperhatikan keunikan anak-anak dan disesuaikan dengan tahap perkembangan kepribadian anak.

\subsection{Pendidikan Anak Dalam Keluarga}

Dalam perspektif sosiologi, keluarga merupakan merupakan suatu kelompok sosial terkecil yang ditandai oleh tempat tinggal bersama, kerjasama ekonomi dan rproduksi (Syarbini, 2014: 20). Keluarga merupakan kelompok sosial pertama dalam kehidupan manusia. Disanalahawal mula pembentukan dan perkembangan sosial manusia termasuk pembentuka norma-norma sosial, interaksi sosial, frame of reference, senses of belongingness, dan lainnya. Pada dasarnya dalam sebuah keluarga terjadi proses reproduksi dan edukasi.

Fungsi edukasi keluarga adalah fungsi yang berkaitan dengan pendidikan anak pada khususnya dan pendidikan keluarga pada umumnya. Dalam hal ini, fungsi edukasi tidak hanya berkaitan dengan pelaksanaannya saja, tetapi menyangkut pula penentuan dan penetapan landasan yang mendasari upaya pendidikan tersebut. Orang tua memiliki 
tanggung jawab melaksanakan fungsi edukasi keluarga terhadap anak-anaknya. Pendidikan anak dalam keluarga merupakan tanggung jawab mendasar bagi orang tua.

Keluarga dan pendidikan adalah dua istilah yang tidak dapat dipisahkan. Di dalam sebuah keluarga akan selalu ada pendidikan yang diberikan, baik pendidikan nilai maupun pendidikan karakter. Berkaitan dengan hal tersebut, sering didengar terdapat istilah pendidikan keluarga. Pendidikan keluarga merupakan pendidikan yang berlangsung dalam keluarga, yang dilaksanakan oleh orang tua sebagai tugas dan tanggung jawabnya mendidik anak dalam keluarga (Djamarah, 2014: 2).

Konsep pendidikan dalam sebuah keluarga dapat diartikan sebagai segala usaha yang dilakukan orang dewasa dalam interaksinya dengan anak-anak untuk membawa perkembangan jasmani dan rohani anak mereka ke arah kedewasaan. Orang dewasa yang dimaksud dalam hal tersebut adalah orang tua (ayah dan ibu) yang secara sadar memberikan pendidikan untuk anak-anaknya. Dalam pendidikan, orang tua memegang peranan sebagai mediator antara anak dan masyarakatnya, antara anak dengan normanorma kehidupan dan antara anak dengan orang dewasa. Melalui pendidikan dalam keluarga, anak akan memenuhi sifat-sifat kemanusiaannya dan berkembang dari insting-insting biogenetik yang primitif untuk belajar respons-respons yang diterimanya (Hasan, 2012: 23). Dengan menempuh proses-proses tersebut, maka anak akan memilikikemampuan dalammengantisipasi kehidupan masyarakat yang sarat akan perubahan dan kompetisi yang snagat ketat.
Keluarga dapat dikatakan sebagai sebuah institusi pendidikan utama yang bersifat kodrati. Keluarga merupakan lingkungan yang paling bertanggung jawab untuk mendidik anak-anak. Pendidikan yang diberikan oleh orang tua haruslah mampu memberikan dasar pendidikan, proses sosialisasi dalam kehidupan anak di masyarakat. Orang tua memegang peranan dalam membentuk sistem interaksi yang intim dan berlangsung dalam waktu yang lama yang ditandai dengan loyalitas pribadi, cinta kasih, dan hubungan yang penuh kasih sayang.

Pendidikan di lingkungan keluarga berlangsung sejak anak lahir bahkan sampai dewasa. Peranan orang tua bagi pendidikan anak adalah memberikan dasar pendidikan, sikap, dan keterampilan dasar (Hasan, 2012: 19). Orang tua memiliki tanggung jawab mewariskan nilai-nilai luhur melalui proses pendidikan dalam keluarga. Keluarga, nilai, dan pendidikan merupakan tiga elemen yang saling berkaitan satu sama lain. Di mana ada keluarga, di situ ada pendidikan, dan di mana ada pendidikan maka di situ ada nilai yang ditanamkan.

Pendidikan dalam keluarga memiliki nilai strategis dalam pembentukan kepribadian anak. Sejak kecil anak mendapatkan pendidikan dari orang tuanya melalui keteladanan dan pembiasaan yang dilakukan sehari-hari dalam lingkungan keluarga. Keteladanan dan kebiasaan yang ditampilan orang tua dalam kehidupan sehari-hari baik dalam bersikap dan berperilaku akan menjadi model bagi anak dan berpengaruh terhadap perkembangan jiwa anak. Anak akan meniru apa yang dilakukan oleh lingkungan sekitarnya, yang sering dikenal dengan belajar melalui imitasi. 


\subsection{Program Parenting}

Keluarga merupakan unit sosial terkecil di masyarakat yang dapat terdiri dari ayah, ibu dan anak yang tinggal pada satu tempat. Sebagai sebuah keluarga, kewajiban orang tua adalah memberi perlindungan, kasih sayang dan lingkungan pebelajaran yang positif bagi anak agar tumbuh kembangnya mnejadi optimal. Orang tua membutuhkan pengetahuan yang menunjang proses pengetahuan yang akan menunjang proses kemandirian dan sikap lainnya pada anak.

Keterlibatan orang tua akan menjadi salah salah penentu dalam keberhasilan program di PAUD. Guru sebagaipendidik kedua harus terus berusaha menjalin komunikasi dan hubungan yang baik dengan orang tua untuk mendapatkan informasiyang tepat tentang anak sehingga dapat mengembangkan potensi anak dengan lebih maksimal. Orang tua juga harus terlibat aktif dalam perencanaan dan pelaksanaan pendidikan anak usia dini di sekolah sehingga terjadi keberlangsungan dan kesinambungan program antara yang dilakukan oleh guru di sekolah dengan orang tua di rumah. Untuk itu, sekolah perlu memiliki dan melaksanakan program pendidikan keorangtuaan (parenting education) yang terjadwal secara rutin.

Parenting education merupakan keterlibatan orang tua dalam sebuah kegiatan yaitu pendidikan bagi orang tua yang bertujuan membantu orang tua untuk menciptakan lingkungan rumah yang aman, nyaman sehingga dapat mendukung anak sebagai pelajar dan mebantu pertumbuhan dan perkembangan anak. Hal tersebut juga berarti bahwa parenting ditujukan untuk membangun pikiran orang tua, sehingga mampu mmebangun potensi yang ada pada diri anak (Latif, dkk; 2013: 261).
Selanjutnya, menurut Helmawati (2015: 60), "parenting merupakan upaya pendidikan yang dilaksanakan oleh keluarga dengan memanfaatkan sumber-sumber yang tersedia dalam keluarga dan lingkungan yang berbentuk kegiatan belajar secara mandiri”. Parenting sebagai proses interaksi berkelanjutan antara orang tua dan anak-anak saat mengalami masa tumbuh dan berkembang yang dapat berupa kegiatan memberi makanan yang sehat (nourishing), memberi petunjuk (guiding), dan melindungi (protecting). Hal tersebut sejalan dengan yang termuat dalam Juknis Orientasi Teknis Peningkatan Program Parenting Tahun 2011, program parenting adalah program dukungan yang ditunjukan kepada para orang tua atau anggota keluarga yang lain agar semakin memilikikemampuandalam melaksanakan fungsi sosial dan pendidikan dalam hal mengasuh, merawat, melindungi, dan mendidik anaknya di rumah sehingga anak dapat tumbuh dan berkembang secara optimal, sesuai dengan usia dan tahapperkembangannya.

Untuk mewujudkan fungsi keluarga khususnya fungsi sosial dan fungsi pendidikan, diperlukan komitmen orang tua sebagai sebuah mitra lembaga PAUD. Program parenting dapat menjadi wadah komunikasi antar orang tua dan juga sebagai bentuk sosialisasi terhadap program-program yang diselenggarakan oleh lembaga PAUD. Tujuan umum dari program parenting ini adalah menyadarkan dan mengajak orang tua untuk bersama-sama memberikan yang terbaik untuk anak-anaknya. Selain itu, secara khsusus, program parenting ini bertujuan: (1) meningkatkan pengetahuan dan keterampilan orang tua dalam melaksanakan perawatan, pengasuhan, dan pendidikan anak di dalam keluarga sendiri berdasarkan nilai-nilai 
karakter, (2) menyelaraskan kepentingan dan keinginan pihak orang tua dan pihak sekolah sehingga sama-sama dapat saling menindaklanjuti, dan (3) menghubungkan program sekolah dengan program pendidikan di rumah sehingga terjadi kerja sama dan kesinambungan stimulasi kepada anak usia dini.

Anak usia dinimenghabiskan waktu mereka dengan berinteraksi di lingkungan sekolah dan rumah. Keberadaan anak di lingkungan sekolah/ lembaga pendidikan anak usia dini hanya $20 \%$ dan sisannya (80\%) adalah di rumah dan dilingkungan sekitarnya. Jika keluarga dan lingkungan tepat tinggal anak tidak dapat mendukung proses pembelajaran yang tepat bagi anak yaitu melalui dunia bermain, maka anak akan kehilangan sebgaian besar proses perkembangannya melaluiproses pembelajaran

(Latif, dkk; 2013: 261). Agar orang tua mengetahui proses pembelajaran yang cocok dan sesuai dengan perkembangan anaknya, berkaitan dengan penyeragangan dan kesinambungan pembelajaran antara di rumah dan di sekolah, maka dibutuhkan parenting sebagai program pembimbing orang tua.

Berbagai jenis kegiatan yang dapat dilakukan oleh orang tua dan lembaga PAUD melalui program parenting (Helmawati, 2015: 63-64), yaitu:

1. Parents gathering; yaitu pertemuan orang tua dengan pihak lembaga PAUD untuk membicarakan program-program lembaga PAUD dalam kaitannya dengan bimbingan dan pengasuhan anak di keluarga. Materi yang dibahas dapat berupa hal yang berkaitan dengan kebutuhan tumbuh kembang anak yang terdiri dari kesehatan dan penyakit pada anak, gizi dan makanan maupun pendidikankarakter.
2. Foundation class; yaitu pembelajaran bersama anak dan orang tua di awal masuk sekolah dalam rangka orientasi dan pengenalan kegiatan di sekolah. Kegiatan ini dapat dilaksanakan pada minggu pertama tahun ajaran baru.

3. Seminar; yaitu kegiatan yang dilaksankan dalam rangka program parenting dengan mengundang tokoh atau praktisi PAUD yang berkompeten.

4. Hari konsultasi; yaitu hari yang disediakan oleh lembaga PAUD untuk orang tua untuk berkonsultasi tentanganaknya.

5. Field trip; yaitu darmawisata, kunjungan wisata, atau kunjungan ke tempat-tempat yang menunjang kegiatan pembelajaran PAUD yang dilakukan bersama orang tua.

6. Home activities; yaitu aktivitas rumah yang dilakukan di sekolah. Bentuk kegiatan ini dengan mengajak orang tua dan anak untuk menginap di sekolah yaitu dapat berupa kegiatan perkemahan.

7. Coocking on the spot; yaitu suatu kegiatan memasak dan mneyajikan makanan yang dilakukan anak bersama orang tua dengan bimbingan guru.

8. Bazar day; yaitu penyelenggaraan kegiatan bazar di lembaga PAUD. Anak-anak akan menampilkan hasil karyanya yang dapat dijual kepada orang tua dan umum.

9. Mini zoo; yaitu menyelenggarakan kebun binatang mini di sekolah. Anak-anak dapat membawa binatang peliharaan dari rumah ke lembagaPAUD.

10. Home education video; yaitu mengirimkan kegiatan pembelajaran anak-anak di lembaga PAUD kepada orang tua dalam bentuk keping CD/DVD, agar orang tua dapat menyaksikannya dirumah. 
Berdasarkan uraian di atas dapat dipahami bahwa agar anak dapat tumbuh dan berkembang dengan sempurna baik fisik, psikis, maupun akalnya, orang tua perlu memiliki pengetahuan tentang pendidikan anak usia dini. Melalui pengetahuan yang dimiliki tersebut, orang tua dapat menjaga, merawat dan mendidik anakanaknya dengan lebih baik. Untuk dapat memperoleh pengetahuan dan ilmu pendidikan untuk anak sejak dini, orang tua dapat mengikuti program parenting yang diselenggarakan oleh lembaga atau satuan PAUD.

\subsection{Pentingnya Keterlibatan Orang Tua dalam Program di PAUD}

Untuk mewujudkan pendidikan anak usia dini yang berkualitas, keterlibatan orang tua dalam program kegiatan anak usia dini sangatlah penting. Orang tua harus menyadari pendidikan untuk anak usia dini bukan hanya menjadi tanggung jawab guru saat anak mulai belajar di sekolah, baik dalam bentuk kelompok bermain maupun Taman Kanak-Kanak (TK). Sebagian besar waktu anak adalah bersama dengan orang tua. Orang tua adalah guru pertama bagi anakanaknya. Namun, setelah anak telah masuk sekolah, peran lain orang tua adalah sebagai mitra kerja yang utama bagi guru di sekolah. Peran orang tua tersebut memungkinkan untuk membantu meningkatkan perkembangan dan pertumbuhan anak usia dini.

Keterlibatan orang tua dalam program di PAUD memiliki arti yang sangat besar. Menurut Morisson, 1998 (dikutip Patmonodewo, 2003: 124), yang dimaksud dengan keterlibatan orang tua adalah suatu proses di mana orang tua menggunakan segala kemampuan yang dimilikinya untuk keuntungan dirinya sendiri, anak-anaknya, dan program yang dijalankannya.
Orang tua, anak dan program sekolah adalah komponen yang tidak dapat dipisahkan, yang menunjang keberhasilan tujuan pendidikan anak usia dini. Selain itu, keterlibatan orang tua dalam program sekolah juga dapat menjadi sebuah kesempatan bagi orang tua untuk belajar meningkatkan pertumbuhan dan perkembangan anak dan mengembangkan hubungan dengan orang tua lain di sekolah.

Usaha yang dilakukan oleh guru dalam mengajar akan lebih efektif hasilnya apabila orang tua ikut membantu dalam pelaksanaan program pendidikan yang telah direncanakan. Demikian juga sebaliknya, apabila orang tua menyadari bahwa program kegiatan sekolah yang dilaksanakan memberikan dampak yang positif bagi perkembangan anaknya, maka orang tua akan senantiasa bersedia terlibat dalam kegiatan yang berhubungan dengan tugas sekolah. Berdasarkan hal tersebut, sekolah dan orang tua senantiasa menjalin komunikasi dan kerja sama terkait dengan penyusunan, pelaksanaan maupun evaluasi program kegiatan di PAUD agar orang tua juga dapat terlibat dan memberikan kontribusi nyata bagi perkembangan anak usia dini. Selain itu, sekolah juga dapat menjalin komunikasi kepada orang tua melalui programparenting yang dicanangkan sekolah, agar orang tua dapat melanjutkan program yang dilakukan di sekolah dapat diperkuat lagi oleh orang tua di rumah.

Orang tua maupun guru PAUD sebenarnya memiliki tujuan yang sama yaitu agar anak didiknya mampu mencapai prestasi dan tumbuh serta berkembang secara optimal. Hal tersebut dapat dicapai apabila orang tua dan guru memiliki pandangan yang sama terhadap pendidikan, utamanya dalam hal ini adalah pendidikan anak usia dini. Partisipasiorang tua 
di PAUD pada umumnya ditujukan untuk membantu anak melewati tugas-tugas perkembangannya yang secara tidak langsung akan menunjang prestasi anak. Berbagai hasil penelitian menunjukkan bahwa apabila orang tua ikut mengambil peran dan terlibat dalam pendidikan, anak akan menunjukkan prestasi belajar, diikuti dengan perbaikan sikap, stabilitas sosio-emosional, kedisiplinan, dan sangat mempengaruhi kesiapan anak untuk masa yang akan datang (Hasan, 2012: 20).

Salah satu hasil penelitian yang menunjang pendapat pentingnya keterlibatan orang tua diperoleh dari studiketerlibatan orang tua dalam program Head Start diAmerika Serikat. Heinz, 1979 (dikutip oleh Padmonodewo, 2003: 124) mengemukakan terdapat tiga hal penting apabila orang tua dan pihak sekolah dapat menjalin kerja sama, yaitu: (1) konsep diri orang tua akan meningkat, (2) motivasibelajar anak meningkat, dan (3) prestasi yang dicapai anak akan meningkat. Dengan demikian dapat dipahami bahwa, keterlibatan orang tua di dalam program PAUD merupakan suatu bentuk kerjasama yang dilakukan oleh orang tua dan guru dalam lingkungan sekolah maupun di rumah demi pertumbuhan dan perkembangan anak usia dini.

\section{PENUTUP}

PAUD merupakan landasan pendidikan yang menentukan kepribadian anak di masa mendatang, sehingga dikatakan anak pada usia dini adalah usia emas. Oleh karena itu pada usia dini wajib diberikan pendidikan, bimbingan dan pengalaman yang positif, sebab kesannya akan disimpan di otaknya sampai hari tuanya Sesuai dengan keunikan danpertumbuhan anak usia dini maka penyelenggaraan pendidikan bagi anak usia dini disesuaikan dengan tahap-tahap perkembangan yang dilalui oleh anak usia dini.

Keberhasilan lembaga PAUD dalam memberikan stimulasi pendidikan kepada anak usia dini tidak terlepas dari peranan dan keterlibatan orang tua di dalamnya. Keterlibatan orang tua dalam program sekolah juga dapat menjadi sebuah kesempatan bagi orang tua untuk belajar meningkatkan pertumbuhan dan perkembangan anak dan mengembangkan hubungan dengan orang tua lain di sekolah.

Usaha yang dilakukan oleh guru dalam mengajar akan lebih efektif hasilnya apabila orang tua ikut membantu dalam pelaksanaan program pendidikanyang telah direncanakan. Demikian juga sebaliknya, apabila orang tua menyadari bahwa program kegiatan sekolah yang dilaksanakan memberikan dampak yang positif bagi perkembangan anaknya, maka orang tua akan senantiasa bersedia terlibat dalam kegiatan yang berhubungan dengan tugas sekolah. Seperti yang diketahui, pedidikan yang dilakukan orang tua dalam lingkup keluarga merupakan dasar bagi anak untuk tumbuh dan berkembang sebelum memperoleh pendidikan di lingkungan sekolah. Pendidikan dalam keluarga memiliki nilai strategis dalam pembentukan kepribadian anak. Sejak kecil anak mendapatkan pendidikan dari orang tuanya melalui keteladanan dan pembiasaan yang dilakukan sehari-haridalamlingkungan keluarga.

Keterlibatan orang tua dalam program PAUD juga tidak terlepas dari program pendidikan keorangtuaan (parenting education). Pendidikan bagi orang tua ini ditujukan agar orang tua memhami pentingnya terlibat dalam program PAUD dan agar orang tua memilikidasar ilmu pendidikan anak usia dini dalam mendidik dan menstimulasi perkembangan 
anak usia dini. Parenting sebagai proses interaksi berkelanjutan antara orang tua dan anak-anak saat mengalami masa tumbuh dan berkembang yang dapat berupa kegiatan memberi makanan yang sehat (nourishing), memberi petunjuk (guiding), dan melindungi (protecting). Melalui pengetahuan yang dimiliki tersebut, orang tua dapat menjaga, merawat dan mendidik anak-anaknya dengan lebih baik.

\section{DAFTAR PUSTAKA}

Djamarah, Syaiful Bahri. 2014. Pola Asuh Orang Tua dan Komunikasi dalam Keluarga: Upaya Membangun Citra Membentuk Pribadi Anak. Jakarta: Rineka Cipta.

Hasan, Maimunah. 2012. Pendidikan Anak Usia Dini. Jogjakarta: Diva Press.

Helmawati. 2015. Mengenal dan Memahami PAUD. Bandung: PT Remaja Rosdakarya.
Kementrian Pendidikan Nasional. 2011. Petunjuk Teknis Orientasi Teknis Peningkatan Pemahaman Program Penguatan PAUD Berbasis Keluarga (Parenting). Jakarta: Kemendiknas

Latif, Mukhtar, dkk. 2013. Orientasi Baru Pendidikan Anak Usia Dini: Teori dan Aplikasi. Jakarta: Kencana.

Patmonodewo, Soemiarti. 2003. Pendidikan Anak Prasekolah. Jakarta: Rineka Cipta.

Santoso, Soegeng. 2011. Konsep Pendidikan Anak Usia Dini Menurut Pedirinya 2. Jakarta: Prodi PAUD UNJ.

Sujiono, Yuliani Nurani. 2011. Konsep Dasar Pendidikan Anak Usia Dini. Jakarta: Indeks.

Suratno. 2005. Pengembangan Kreativitas Anak Usia Dini. Jakarta: Depdiknas.

Syarbini, Amirulloh. 2014. Model Pendidikan Karkater dalam Keluarga. Jakarta: PT Elex MediaKomputindo. 